\title{
TINJAUAN PEMUNGUTAN, PERHITUNGAN, DAN PELAPORAN PAJAK PENGHASILAN PASAL 21 ATAS GAJI PEGAWAI TETAP PADA DINAS PENDAPATAN PEMERINTAH KOTA CIMAHI
}

\author{
Dedy Suryadi ${ }^{(1)}$, Lisnawati(2) \\ Program Studi Komputerisasi Akuntansi ${ }^{(1)}$, Program Studi Akuntansi ${ }^{(2)}$ Politeknik TEDC Bandung \\ Email: dsuryadi@poltektedc.ac.id
}

\begin{abstract}
Abstrak
Tinjauan Pemungutan, Perhitungan, dan Pelaporan Pajak Penghasilan Pasal 21 atas Gaji Pegawai Tetap Pada Dinas Pendapatan Pemerintah Kota Cimahi, yang bertujuan untuk menganalisis pemungutan, perhitungan, dan pelaporan Pajak Penghasilan Pasal 21 atas gaji pegawai tetap pada Dinas Pendapatan Pemerintah Kota Cimahi. Metode penelitian yang digunakan adalah metode analisis deskriptif meliputi kegiatan observasi, studi kepustakaan, dan wawancara. Berdasarkan hasil analisis yang dilakukan dalam pemungutan Pajak Penghasilan Pasal 21 sudah sesuai dengan Peraturan Menteri Keuangan Nomor 262/KMK.03/2010. Untuk perhitungan Pajak Penghasilan Pasal 21 dengan menggunakan PTKP (Penghasilan Tidak Kena Pajak) terbaru Dinas Pendapatan Pemerintah Kota Cimahi baru menerapkannya pada bulan november 2015. Pelaporan yang dilakukan Dinas Pendapatan Pemerintah Kota Cimahi pada tahun 2015 terdapat $91,67 \%$ pelaporan yang sesuai dan $8,33 \%$ yang tidak sesuai dengan Undang-Undang Nomor 36 Tahun 2008. Pada tahun 2013 sampai tahun 2014 Dinas Pendapatan Pemerintah Kota Cimahi tidak melaporkan Pajak Penghasilan Pasal 21 dikarenakan kurangnya kesadaran akan kewajibannya melaporkan pajak. Oleh karena itu Dinas Pendapatan Pemerintah Kota Cimahi dikenakan sanksi administrasi berupa bunga sebesar $2 \%$ (dua persen) atas keterlambatan penyetoran dan sanksi administrasi berupa denda sebesar Rp.1.000.000,- atas keterlambatan pelaporan pajak.
\end{abstract}

Kata Kunci: Pemungutan, Perhitungan, Pelaporan, PPh Pasal 21 Pegawai Tetap

\begin{abstract}
Review Collection Calculations And Reporting Income Tax Article 21 On Employee Salaries Remain At Dinas Pendapatan Pemerintah Kota Cimahi, which has purposed to analyze Collection, Calculations, and reporting Income Tx Article 21 On Employee Salaries Remain At Dinas Pendapatan Pemerintah Kota Cimahi. The research method which is used in this research is descriptive analysis method include observation, study of librarianship, and interviews. Based on the results of analysis conducted in Income Tax collection Article 21 in accordance with Peraturan Menteri Keuangan Nomor 262/KMK.03/2010. To review the calculations of Income Tax Article 21 by using PTKP (non-taxable income) latest new apply by month November 2015. In reporting which is conducted Dinas Pendapatan Pemerintah Kota Cimahi in 2015 there 91,67\% appropriate reporting and 8,33\% which is not in accordance with Undang-Undang Nomor 36 Tahun 2008. The year 2013 to 2014 years Dinas Pendapatan Pemerintah Kota Cimahi not reporting Income Tax Article 21 due to lack of awareness of the tax reporting obligations. As a result Dinas Pendapatan Pemerintah Kota Cimahi administration charge in the form of an annual interest rate $2 \%$ (two percent) for the late deposit and administration charge the form penalty charge amountimg Rp. 1.000.000,- on late payment of tax.
\end{abstract}

Keywords: Collection, Calculations, Reporting Income Tax Article 21 Employee Salaries

\section{PENDAHULUAN}

Pajak adalah salah satu sumber penerimaan negara yang paling diandalkan selain minyak bumi, gas alam dan hibah (Penerimaan negara bukan pajak). Dalam Tabel 1. terlihat kontribusi penerimaan pajak terhadap pendapatan negara cenderung meningkat setiap tahunnya. Dalam Anggaran Pendapatan dan Belanja Negara (APBN) tahun 2015 penerimaan dari sektor pajak sebesar Rp.1.201,7 triliun atau $67 \%$ dari seluruh penerimaan negara yang berarti sektor pajak adalah penyumbang terbesar dalam penerimaan negara dibandingkan dengan penerimaan negara bukan pajak sebesar Rp. 561,9 atau $33 \%$ dari seluruh penerimaan negara.
Tabel 1. Realisasi dan target penerimaan pajak tahun 2010-2015

\begin{tabular}{|c|c|c|c|c|c|}
\hline \multirow[t]{2}{*}{ Tahun } & \multicolumn{2}{|c|}{ Penerimaan Pajak } & \multicolumn{2}{|c|}{$\begin{array}{c}\text { Penerimaan Negara } \\
\text { Bukan Pajak Dan Hibah }\end{array}$} & \multirow{2}{*}{$\begin{array}{c}\text { Penerima } \\
\text { an Negra }\end{array}$} \\
\hline & Triliun & Kontribusi & Triliun & Kontribusi & \\
\hline 2011 & 839 & $70 \%$ & 371,6 & $30 \%$ & $1.210,60$ \\
\hline 2012 & 930,8 & $70 \%$ & 357,5 & $30 \%$ & 1.338 \\
\hline 2013 & $1.099,9$ & $73 \%$ & 353,6 & $27 \%$ & 1.502 \\
\hline 2014 & $1.226,4$ & $75 \%$ & 386,7 & $25 \%$ & $1.667,14$ \\
\hline 2015 & $1.201,7$ & $67 \%$ & 561,9 & $33 \%$ & $1.763,6$ \\
\hline
\end{tabular}

Sumber:Kementrian Keuangan Republik Indonesia (2015) 
Pemotongan pajak sebagai pihak yang mempunyai hak dan kewajiban untuk melakukan pemungutan, penghitungan, dan pelaporan PPh 21 harus mempunyai pemahaman yang baik dan benar tentang peraturan perundang-undangan PPh 21 yang berlaku saat ini. Kurangnya pemahaman pemotong pajak terhadap sistem peraturan yang berlaku dapat menimbulkan kesalahan dalam penghitungan, pelaporan dan penyetoran PPh Pasal 21, dan hal ini tentu saja dapat mengakibatkan kerugian bagi perusahaan, pegawai dan terutama bagi pemerintah karena dapat menyebabkan hilangnya potensi pajak pemerintah.

Pengenaan Pajak Penghasilan Pasal 21 terhadap Pegawai Negeri Sipil (PNS) dilakukan berdasarkan peraturan pemerintah nomor 80 tahun 2010 tentang Pajak Penghasilan bagi pegawai negeri sipil. Tata cara pemungutan Pajak Penghasilan Pasal 21 bagi pegawai negeri sipil dilakukan berdasarkan Peraturan Menteri Keuangan Nomor 262/KMK.03/2010. Pemungutan pajak penghasilan pasal 21 atas pemotongan pajak oleh bendaharawan pemerintah baik pusat maupun daerah dananya dibiayai dari Anggaran Pendapatan dan Belanja Negara (APBN), atau Anggaran Pendapatan dan Belanja Daerah (APBD).

Dalam menghitung PPh Pasal 21 pegawai negeri sipil banyak hal yang perlu diperhatikan. Salah satunya adalah berbagai kebijakan terkait dengan jenis pajak penghasilan tersebut, kebijakan dalam perhitungan Pajak Penghasilan Pasal 21 yaitu terkait dengan metode perhitungannya, dan metode perhitungan PPh Pasal 21 yang digunakan Dinas Pendapatan Pemerintah Kota Cimahi menggunakan metode perhitungan Gross-Up, yaitu dimana instansi pemerintahan memberikan tunjangan pajak yang besarnya sama besar dengan PPh Pasal 21 yang dipotong atas penghasilan pegawainya.

Penghasilan yang diterima pegawai negeri sipil menurut Menteri Keuangan Nomor 262/PMK.03/2010 yaitu : Gaji pokok, tunjangan anak, tunjangan suami/istri, tunjangan struktural atau fungsional, tunjangan beras dan tunjangan khusus yaitu, Iuran pensiun untuk PNS sebesar $4,75 \%$ dan tunjangan hari tua PNS sebesar 3,25\%. Dinas Pendapatan Pemerintah Kota Cimahi merupakan instansi pemerintah yang berlokasi di Daerah Cimahi, Dinas Pendapatan Pemerintah kota Cimahi sebagai wajib pajak badan yang harus memungut, menghitung dan melaporkan Pajak Penghasilan Pasal 21. Pajak yang terutang tersebut harus disetorkan ke kas negara. Penyetoran pajak penghasilan menggunakan dokumen yang diperlukan untuk diserahkan ke kantor pajak. Dalam penyetoran pajak penghasilan atas gaji pegawai negeri sipil terdapat mekanisme yang harus ditaati, perlu adanya pembahasan yang menunjukkan mekanisme Pajak Penghasilan Pasal 21 atas pegawai negeri sipil yang selama ini terjadi apakah sesuai dengan Peraturan Direktorat Jenderal Pajak PER-31/PJ/2015.

Melalui Peraturan Direktorat Jenderal Pajak PER-31/PJ/2015 besarnya Penghasilan Tidak Kena Pajak terhitung mulai tanggal 1 januari 2015 telah ditetapkan dalam peraturan Menteri Keuangan Nomor 122/PMK.010/2015 tentang penyesuaian besarnya Penghasilan Tidak Kena Pajak. Pajak terutang yang telah dihitung, disetorkan, dan dilaporkan pada bulan januari sampai juni harus dihitung kembali pada akhir tahun menggunakan PTKP terbaru sesuai dengan peraturan Menteri Keuangan Nomor 122/PMK010/2015 . jika ada kelebihan pajak dipotong maka tidak direstitusi tetapi diperhitungkan dengan pajak terutang bulan-bulan berikutnya sampai dengan bulan desember 2015.

\section{TINJAUAN PUSTAKA}

\section{Pajak Penghasilan Pasal 21}

UU No.7 tahun 1983 tentang PPh. Sebagaimana telah beberapa kali diubah, terakhir diubah dengan UU No.36 tahun 2008 ( dalam uraian selanjutnya digunakan singkatan UU PPh ). UU No.36 tahun 2008 tentang perubahan keempat atas UU N0.7 tahun 1983 tentang PPh, menyatakan, ketentuan Pasal 21 ayat (1) sampai dengan ayat (5), dan ayat (8) diubah, serta diantaranya ayat (5) dan ayat (6) disisipkan 1 (satu) ayat, yakni ayat (5a), sehingga berdasarkan Pasal 21 UU PPh hasil perubahan dan penjelasannya serta ketentuan pelaksanaannya, aturan tentang PPh.

Menurut Peraturan Direktur Jenderal Pajak Nomor PER-32/PJ/2015, Pajak Penghasilan Pasal 21 (PPh Pasal 21) adalah pajak atas penghasilan berupa gaji, upah, honorarium, tunjangan, dan pembayaran lain dengan nama dan dalam bentuk apapun sehubungan dengan pekerjaan atau jabatan, jasa, dan kegiatan yang dilakukan oleh orang pribadi subyek pajak dalam negeri.

Menurut Rudy Suhartono dan Wirawan B.Ilyas $(2011 ; 96)$, menyatakan bahwa :

"Pajak Penghasilan Pasal 21 adalah pajak atas penghasilan berupa gaji, upah, honorarium, tunjangan-tunjangan, dan pembayaran lain dengan nama dan dalam bentuk apapun sehubungan dengan pekerjaan atau jabatan, jasa dan kegiatan yang diterima atau diperoleh Wajib Pajak Orang Pribadi (WP OP) ."

Sebagaimana dikemukakan oleh Siti Resmi $(2011 ; 163)$, menyatakan bahwa :

"Pajak Penghasilan Pasal 21 merupakan pajak atas penghasilan berupa gaji, upah, honorarium, tunjangan, dan pembayaran lain dengan nama dan dalam bentuk apapun sehubungan dengan pekerjaan atau jabatan, jasa, dan kegiatan yang dilakukan oleh wajib pajak orang pribadi dalam negeri." 


\section{Pemotong PPh Pasal 21 Wajib Memotong, Menyetor, dan Melapor (Pasal 21 (1) UU PPh)}

Pemotong pajak atas penghasilan sehubungan dengan pekerjaan, jasa, atau kegiatan dengan nama dan dalam bentuk apapun yang diterima atau diperoleh WP orang pribadi dalam negri wajib dilakukan oleh :

1. Pemberi Kerja, pemberi kerja yang membayar gaji, upah, honorarium, tunjangan, dan pembayaran lain sebagai imbalan sehubungan dengan pekerjaan yang dilakukan oleh pegawai atau bukan pegawai.

2. Bendaharawan Pemerintah, Bendahara Pemerintah yang membayar gaji, upah, honorarium, tunjangan, dan pembayaran lain sehubungan dengan pekerjaan, jasa, atau kegiatan.

3. Dana pensiun atau dana lain. Dana pensiun atau badan lain yang membayarkan uang pensiun dan pembayaran lain dengan nama apapun dalam rangka pensiun.

4. Badan yang membayar honorarium atau pembayaran lain sebagai imbalan sehubungan dengan jasa termasuk jasa tenaga ahli yang melakukan pekerjaan bebas.

\section{Tarif Pajak Penghasilan Pasal 21}

Sesuai dengan pasal 17 ayat 1 , UndangUndang No.36 tahun 2008 tarif Pajak Penghasilan pribadi perhitungannya dengan menggunakan tarif progresif sebagai berikut :

1. Penghasilan Kena Pajak

Sistem penerapan tarif pajak penghasilan sesuai dengan pasal 17 ayat 1 UU PPh wajib pajak orang pribadi dalam negeri sebagai berikut :

Tabel 2. Penghasilan kena pajak

\begin{tabular}{|c|c|}
\hline Penghasilan Kena Pajak & Tarif \\
\hline Sampai dengan Rp. 50.000 .000 & $5 \%$ \\
\hline Rp. $50.000 .000-$ Rp. 250.000 .000 & $15 \%$ \\
\hline Rp. $250.000 .000-$ Rp. 500.000 .000 & $25 \%$ \\
\hline Lebih dari Rp. 500.000 .000 & $30 \%$ \\
\hline
\end{tabular}

2. Tarif khusus PPh Pasal 21

Sistem penerapan tarif khusus pajak penghasilan sesuai dengan PMK Nomor 262/KMK.03/2010 Tentang honorarium pejabat negara, PNS, Anggota TNI, anggota polri dan pensiunan :

a. Tarif khusus berikut diterapkan atas penghasilan yang bersumber dari APBN yang diterima oleh Pejabat PNS, anggota TNI/Polri, dan Pensiunan.

b. Tarif $0 \%$ dari jumlah bruto honorarium atau imbalan bagi PNS golongan I dan golongan II, Anggota TNI/Polri golongan pangkat Perwira Tamtama dan Bintara, dan Pensiunannya.

c. Tarif $5 \%$ dari jumlah bruto honorarium atau imbalan bagi PNS golongan III, anggota TNI/Polri golongan Pangkat Perwira Pertama, dan pensiunannya.

d. Tarif $15 \%$ dari jumlah bruto honorarium atau imbalan bagi PNS golongan IV, Anggota TNI/Polri golongan Pangkta Perwira Menengah dan Tinggi, dan pensiunannya.

Tarif khusus ditetapkan atas penghasilan berupa uang pensiun yang diterima sekaligus.

Tabel 3. Tarif khusus penghasilan uang pensiun

\begin{tabular}{|c|c|}
\hline Tarif & Penghasilan Bruto \\
\hline $0 \%$ & Sampai dengan Rp. 25.000.000 \\
\hline $5 \%$ & Rp 25.000.000 - Rp. 50.000 .000 \\
\hline $15 \%$ & Rp. $100.000 .000-$ Rp. 200.000 .000 \\
\hline $25 \%$ & Diatas Rp. 200.000.000 \\
\hline \multicolumn{2}{|c|}{ Sumber : Direktorat Jenderal Pajak (2008) }
\end{tabular}

Tarif khusus ditetapkan atas penghasilan berupa uang manfaat pensiun, tunjangan hari tua, atau jaminan hari tua; a) tarif $0 \%$ atas penghasilan bruto samapai dengan Rp. 500.000 .000 ; b) tarif $5 \%$ atas penghasilan bruto diatas Rp. 50.000 .000 .

Tarif khusus $5 \%$ atas upah harian, borongan satuan yang diterima oleh tenaga kerja harian lepas yang mempunyai total upah sebulan kurang dari Rp. 3.000.000 dan upah sehari kurang dari Rp. 300.000.

3. Metode Perhitungan Pajak Penghasilan Pasal 21

Menurut Chairil Anwar Pohan (2011;91) ada tiga metode yang biasanya digunakan dalam perhitungan pajak penghasilan pasal 21 dalam menjalankan perencanaan pajak yaitu :

a. Net Method adalah PPh Pasal 21 ditanggung sendiri oleh pemberi penghasilan. Dalam hal ini, perusahaan atau instansi akan menanggung semua PPh Pasal 21 atas pegawai, sehingga akan diperlakukan sebagai beban perusahaan.

b. Gross Method adalah metode pemotongan pajak dimana PPh Pasal 21 ditanggung oleh penerima penghasilan. Penghasilan yang diterima pegawai akan dipotong sesuai besarnya pajak penghasilan terutang masing-masing pegawai sehingga menjadikan penghasilan bersih pegawai berkurang.

c. Gross-Up Method adalah metode dimana perusahaan memberikan tunjangan pajak sama besar dengan PPh Pasal 21 yang dipotong atas gaji pegawainya. 
Pajak Penghasilan Pasal 21 Pegawai Negeri Sipil

Dasar pengenaan PPh Pasal 21 dinyatakan dalam Pasal 9PMK.252/PMK.03/2008, yaitu :

1. Dasar pengenaan PPh Pasal 21 atas penghasilan tetap dan teratur setiap bulan adalah Penghasilan Kena Pajak (PKP) .

2. Besarnya Penghasilan Kena Pajak adalah penghasilan neto dikurangi penghasilan Tidak Kena Pajak.

3. Besarnya penghasilan neto bagi Pejabat Negara,PNS,Anggota TNI,atau Anggota PORLI adalah jumlah seluruh penghasilan tetap dan teratur setiap bulan dikurangi dengan biaya jabatan dan iuran yang terkait dengan gaji yang dibayar kepada dana pensiun atau badan penyelenggara tunjangan hari tua atau jaminan hari tua yang pendiriannya telah disahkan oleh Menteri Keuangan.

4. Besarnya penghasilan neto bagi pensiunan ditentukan berdasarkan seluruh penghasilan tetap dan teratur setiap bulan dikurangi dengan biaya pensiun.

5. Dasar penggenaan PPh Pasal 21 atas honorarium atau imbalan lain dengan nama apapun adalah penghasilan bruto .

6. Besarnya PTKP bagi wanita berlaku ketentuan sebagai berikut :

a. Bagi wanita kawin, sebesar PTKP untuk dirinya sendiri.

b. Bagi wanita tidak kawin, sebesar PTKP untuk dirinya sendiri ditambah PTKP untuk keluarga sedarah dan keluarga semenda dalam garis keturunan lurus serta anak angkat, yang menjadi tanggungan sepenuhnya paling banyak tiga orang.

\section{Tarif Pemotongan Pajak Dan Penetapannya}

Tarif pemotongan Pajak dan penerapannya dinyatakan dalam Pasal 13 PMK.252/PMK.03/2008, yaitu :

1. Tarif pajak berdasarkan Pasal 17 Ayat (1) Huruf a UU PPh diterapkan atas Penghasilan Kena Pajak.

2. Jumlah PKP sebagai dasar penerapan tarif dibulatkan kebawah hingga ribuan rupiah penuh.

3. Untuk perhitungan PPh Pasal 21 yang harus dipotong setiap masa pajak, selain masa pajak Desember atau masa pajak terakhir. Tarif pajak ditetapkan atas perkiraan penghasilan yang akan diperoleh selama satu tahun dengan ketentuan sebagai berikut:

a. Perkiraan penghasilan yang akan diperoleh selama satu tahun adalah jumlah gaji, uang pensiun, dan tunjangan yang dibayar setiap bulan dikalikan 12 . b. Dalam hal terdapat pembayaran penghasilan seperti gaji, uang pensiun, dan tunjangan ke-13, serta rapel dan atau tunjangan maka perkiraan penghasilan yang akan diperoleh selama satu tahun adalah sebesar jumlah pada huruf a ditambah dengan jumlah gaji, uang pensiun, dan tunjangan ke-13 serta rapel gaji dan atau tunjangan.

4. Jumlah PPh Pasal 21 yang harus dipotong untuk setiap masa pajak adalah sebagai berikut :

a. Atas penghasilan sebagaimana dimaksud Pada point 3 huruf a

b. Atas penghasilan seperti gaji, uang pensiun, dan tujangan ke-13 serta rapel gaji dan atau tunjangan adalah sebesar selisih antara Pajak Penghasilan yang terutang atas jumlah penghasilan sebagaimana dimaksud pada point 3 huruf $\mathrm{b}$ dengan Pajak Penghasilan yang terutang atas Penghasilan sebagaimana dimaksud dalam tahun takwin yang bersangkutan.

5. Besarnya PPh Pasal 21 yang dipotong untuk masa Pajak Desember adalah selisih antara PPh yang terutang atas seluruh PKP selama satu tahun takwin yang akumulasi PPh Pasal 21 yang terutang pada masa pajak masa sebelumnya dalam tahun takwin yang bersangkutan .

6. Tidak termasuk dalam akumulasi PPh Pasal 21 yang terutang adalah tambahan PPh Pasal 21 lebih tinggi $20 \%$.

\section{Tarif PPh Pasal 21 Bersifat Final}

Tabel 4. Tarif PPh Pasal 21 Bersifat Final

\begin{tabular}{|c|c|}
\hline Tarif & Golongan \\
\hline $0 \%$ & PNS Golongan I dan Golongan II \\
\hline $5 \%$ & PNS Golongan III \\
\hline $15 \%$ & PNS Golongan VI \\
\hline
\end{tabular}

Sumber : PP Nomor 80 (2010)

\section{Iuran Wajib Pajak Pegawai Negeri Sipil}

Tabel 5. Iuran wajib pajak pegawai negeri sipil

\begin{tabular}{|c|c|}
\hline $4,75 \%$ & Iuran pensiun \\
\hline $3,75 \%$ & Tunjangan Hari Tua \\
\hline
\end{tabular}

\section{Tunjangan Untuk Pegawai Negeri Sipil}

Tunjangan-tunjangan yang diberikan kepada Pegawai Negeri Sipil adalah sebagai berikut : 
1. Tunjangan istri/suami

Tunjangan ini diberikan bagi PNS yang telah berkeluarga, baik itu suami atau istri. Masingmasing akan mendapatkan tunjangan istri/suami dengan besaran $10 \%$ dari gaji pokok dengan aturan yang berlaku. Salah satu aturan tersebut adalah bagi suami istri yang berkedudukan sama sebagai PNS maka tunjangan keluarga tidak diberikan kepada dua-duanya tetapi diberikan kepada salah satu yang gaji pokok nya paling tinggi.

2. Tunjangan anak

Tunjangan anak diberikan jika dalam satu keluarga memiliki anak baik anak kandung maupun anak angkat, masing-masing akan mendapatkan $2 \%$ dari gaji pokok. Aturannya adalah anak yang mendapatkan tunjangan berusia maximal 25 tahun namun belum memiliki pendapatan sendiri, belum pernah menikah dan masih menjadi tanggungan dari orang tuanya yang berstatus sebagai PNS . Dan jumlah anak yang mendapatkan tunjangan adalah dibatas hanya untuk dua anak.

3. Tunjangan Jabatan Umum

Tunjangan-tunjangan yang didapat oleh PNS tidak sekedar tunjangan yang harus diterima oleh keluarga saja namun juga dengan tunjangan atas posisi yang didudukinya. Tunjangan umum diberikan dengan tujuan untuk memaksimalkan kinerja serta mendorong pegawai untuk lebih semangat mencapai prestasi kerja.

Tabel 6. Tunjangan jabatan umum

\begin{tabular}{|c|c|}
\hline Golongan PNS & $\begin{array}{c}\text { Besar Tunjangan Jabatan } \\
\text { Umum }\end{array}$ \\
\hline Gol. VI & Rp. 190.000,- \\
\hline Gol. III & Rp. 185.000,- \\
\hline Gol. II & Rp. 180.000,- \\
\hline Gol. I & Rp. 175.000,- \\
\hline
\end{tabular}

4. Tunjangan Jabatan Struktural

Tunjangan yang diberikan kepada pegawai negeri yang berkedudukan sebagai pejabat struktural yang didasarkan berdasarkan jabatan eselon, seperti pada table 7 .

5. Tunjangan Beras

Tunjangan beras diberikan kepada pegawai negeri sipil setiap bulan berdasarkan pada harga beras yang berlaku pada saat ini. Namun biasanya besarnya ditentukan atas harga pembelian oleh pemerintah kepada perum bulog. Pembayaran tunjangan ini dibedakan atas dua jenis yaitu natura dan uang . harga beras pada tahun ini adalah Rp. 7.242,- pembayaran tunjangan dibatasi hanya untuk dua orang anak saja dengan masing-masing mendapatkan $10 / \mathrm{kg}$ perbulan.

Tabel 7. Tunjangan Jabatan Struktural

\begin{tabular}{|c|c|}
\hline Eselon & Besar Tunjangan Struktural \\
\hline I A & Rp. 5.500.000,- \\
\hline I B & Rp. 4.375.000,- \\
\hline II A & Rp. 3.250.000,- \\
\hline II B & Rp. 2.025.000,- \\
\hline III A & Rp. $1.260 .000,-$ \\
\hline III B & Rp. $980.000,-$ \\
\hline IV A & Rp. 540.000,- \\
\hline IV B & Rp. 490.000,- \\
\hline V A & Rp. 360.000,- \\
\hline
\end{tabular}

6. Tunjangan Khusus Pajak

Tunjangan untuk pemotong pajak atas penghasilan yang didapatkan oleh PNS, TNI, dan POLRI, baik yang masih aktif kerja ataupun yang telah memasuki masa pensiun. Pemotongan dilakukan secara otomatis dengan dibebankan kepada APBN atau APBD.

\section{METODE PENELITIAN}

\section{Data yang Dibahas}

Dalam menyusun laporan penelitian ini penulis memerlukan data sekunder. Data sekunder yaitu data yang diperoleh tidak langsung yang merupakan data yang telah diolah. Dari data yang diperoleh dari Dinas Pendapatan Pemerintah kota Cimahi, yang termasuk data sekunder adalah :

\section{SPT Masa}

SPT Masa adalah untuk mengetahui surat yang diperoleh oleh WP yang digunakan untuk melaporkan perhitungan dan pembayaran pajak terutang dalam suatu masa/bulan pajak .

2. SPT Tahunan

SPT Tahunan adalah untuk mengetahui surat yang diperoleh oleh WP yang digunakan untuk melaporkan perhitungan dan pembayaran pajak terutang tahunan.

3. Data Pegawai

Data pegawai adalah untuk mengetahui identitas pegawai.

4. Daftar Gaji Pegawai

Daftar gaji pegawai adalah untuk mengetahui jumlah penghasilan pegawai yang diperoleh tiap bulan.

5. Profil Perusahaan Dinas Pendapatan Kota Cimahi

Profil Perusahaan adalah sejarah singkat berdirinya Dinas Pendapatan Kota, kegiatankegiatan yang dilaksanakan serta struktur organisasi untuk mengetahui sub-sub jabatan yang ada di Dinas Pendapatan Kota Cimahi.

\section{Pengolahan Data}

Dalam mengidentifikasi dan memahami permasalahan yang dihadapi maka penulis hendak 
melakukan metode deskriptif analisis yaitu metode penelitian yang digunakan untuk menemukan pengetahuan yang seluas-luasnya terhadap objek penelitian. Dengan menggunakan teknik pengumpulan data antara lain :

1. Penelitian Kepustakaan; yaitu penelitian yang dilaksanakan dengan membaca, mempelajari, dan menyimpulkan berbagai referensi dan bahan perkuliahan khususnya yang ada hubungannya dengan masalah yang sedang diteliti.

2. Penelitian Lapangan; yaitu penelitian yang dilaksanakan dengan meninjau secara langsung pada lokasi perusahaan. Penelitian lapangan terbagi dua, yaitu :

a. Wawancara; yaitu kegiatan dengan mengadakan komunikasi langsung dengan para pegawai yang terkait dengan masalah yang diteliti dengan tujuan memperoleh informasi dari yang diteliti.

b. Pengamatan; Suatu cara untuk mendapatkan data dengan melakukan pengamatan dan penelitian secara langsung, kemudian hasil pengamatan dicatat dan dianalisis.

\section{Analisis Permasalahan}

Dalam penelitian yang dilakukan pada Dinas Pendapatan Kota Cimahi penulis mencoba melakukan analisis permasalahan yang sesuai dengan rumusan masalah yang diajukan, yaitu pemungutan, perhitungan, pelaporan PPh Pasal 21 di Dinas Pendapatan Kota Cimahi.

a. Pemungutan PPh Pasal 21

Pemungutan atas pengeluaran yang berasal dari APBN/APBD adalah bendaharawan pemerintah. Sebagai pihak yang melakukan pemungutan pajak, bendaharawan pemerintah harus mengetahui aspek-aspek perpajakan terutama yang berkaitan dengan kewajiban untuk melakukan pemungutan pajak penghasilan pasal 21.

b. Perhitungan PPh Pasal 21

Perhitungan Pajak Penghasilan atas pegawai negeri sipil dihitung menggunakan metode gross up dan berdasarkan gaji pokok, tunjangan anak, tunjangan suami/istri, tunjangan struktural atau fungsional, tunjangan beras dan tunjangan khusus. Iuran wajib pegawai negeri sipil 4,75\% untuk iuran pensiun 3,25\% untuk tunjangan hari tua. Dan untuk penghasilan yang bersifat final golongan III dipotong sebesar $5 \%$ dan golongan IV dipotong sebesar $15 \%$. perhitungan yang dilakukan menggunakan peraturan Menteri Keuangan Nomor 122/PMK010/2015.

c. Pelaporan PPh Pasal 21

Pelaporan Pajak Penghasilan Pasal 21 pada Dinas Pendapatan Daerah Kota Cimahi dilaporkan oleh bendaharawan pemerintahan.

\section{HASIL DAN PEMBAHASAN}

Pembahasan tentang pemungutan, perhitungan, dan pelaporan Pajak Penghasilan Pasal 21 atas gaji pegawai tetap yang dilakukan Dinas Pendapatan Pemerintah Kota Cimahi adalah sebagai berikut :

\section{Pemungutan Pajak Penghasilan Pasal 21}

Pemungutan atas pengeluaran yang berasal dari APBN/APBD adalah bendaharawan pemerintah. Sebagai pihak yang melakukan pemungutan pajak, bendaharawan pemerintah harus mengetahui aspek-aspek perpajakan terutama yang berkaitan dengan kewajiban untuk melakukan pemungutan pajak penghasilan pasal 21.

Jumlah PPh Pasal 21 yang harus dipungut untuk masa pajak adalah penghasilan yang bersifat teratur atas jumlah penghasilan teratur dalam satu tahun. Besarnya PPh Pasal 21 yang harus dipungut untuk masa pajak terakhir adalah selisih antara Pajak Penghasilan yang terutang atas seluruh penghasilan kena pajak selama satu tahun pajak. Kewajiban pajak pegawai tetap dihitung berdasarkan Penghasilan Kena Pajak yang disetahunkan. Bagi penerima penghasilan yang dipotong PPh Pasal 21 yang tidak memiliki Nomor Pokok Wajib Pajak, dikenakan pemungutan PPh Pasal 21 dengan tarif lebih tinggi 20\%.

Pemungutan Pajak Penghasilan Pasal 21 harus memberikan bukti pemungutan/bukti pemotongan PPh Pasal 21 yaitu formulir 1721-A2 atas penghasilan yang diterima atau diperoleh pegawai negeri sipil yang terdiri dari dua rangkap yaitu untuk digunakan oleh :

1. Lembar ke - 1 : Untuk penerima penghasilan.

2. Lembar ke - 2 : Untuk pemotong pajak penghasilan pasal 21.

Bukti potong Pajak Penghasilan Pasal 21 diserahkan paling lama satu bulan. Jumlah pemungutan PPh Pasal 21 merupakan kredit pajak bagi penerima penghasilan yang dikenakan pemungutan untuk tahun pajak yang bersangkutan.

\section{Perhitungan Pajak Penghasilan Pasal 21}

Pajak Penghasilan Pasal 21 merupakan pajak yang terutang atas penghasilan yang menjadi kewajiban wajib pajak untuk membayarnya. Penghasilan yang dimaksud adalah berupa gaji, honorarium, tunjangan, dan pembayaran lain dengan nama apapun sehubungan dengan pekerjaan jasa atau kegiatan yang dilakukan oleh wajib pajak dalam negeri sebagaimana telah diatur dalam pasal 21 perundang-undangan nomor 36 tahun 2008.

Perhitungan Pajak Penghasilan Pasal 21 pada tahun 2015 tidak sesuai dengan Peraturan Direktorat Jenderal Pajak PER-31/PJ/2015, penyesuaian besarnya Penghasilan Tidak Kena 
Pajak (PTKP) terhitung mulai 1 januari 2015 yang ditetapkan dalam Peraturan Menteri Keuangan Nomor 122/PMK010/2015. Dinas Pendapatan Pemerintah Kota Cimahi baru menerapkan PTKP terbaru pada bulan November 2015. Pajak terutang pada bulan januari sampai bulan oktober yang telah dihitung, disetorkan, dan dilaporkan dengan menggunakan PTKP lama dapat dilakukan pembetulan menggunakan PTKP terbaru, dalam hal kelebihan setor akibat pembetulan penghitungan PPh Pasal 21 Masa Pajak januari sampai oktober bendaharawan pemerintah dapat mengkompensasikan kelebihan setor tersebut terhadap PPh Pasal 21 masa pajak bulan november sampai dengan bulan Desember 2015.

\section{Pelaporan Pajak Penghasilan Pasal 21}

Dinas Pendapatan Pemerintah Kota Cimahi menyetorkan pajak penghasilan pasal 21 ke bank persepsi. Penyetoran Pajak Penghasilan Pasal 21 dilakukan pada Bank BJB Cimahi. Sarana yang digunakan untuk menyetorkan Pajak Penghasilan Pasal 21 adalah Surat Setoran Pajak (SSP) yang telah diisi atas nama wajib pajak serta ditandatangani oleh pemungut pajak. Yang terdiri dari lima rangkap yaitu untuk digunakan oleh :

1. Lembar ke satu : Untuk arsip Wajib Pajak.

2. Lembar ke dua : Untuk Kantor Pelayanan Perbendaharaan Negara (KPPN).

3. Lembar ke tiga : Untuk dilaporkan oleh Wajib Pajak ke KPP.

4. Lembar ke empat : Untuk arsip kantor penerimaan pembayaran.

5. Lembar ke lima : Untuk arsip Wajib Pajak atau pihak lain.

Pada saat penyetoran Surat Setoran Pajak (SSP) lembar satu, tiga dan lima akan dikembalikan untuk digunakan pada saat pelaporan. Keterlambatan penyetoran pajak dikenakan sanksi administrasi yaitu dikenakan sanksi bunga sebesar 2\% (dua persen) yang dihitung dari tanggal jatuh tempo sampai dengan tanggal jatuh tempo pembayaran dan bagian dari bulan dihitung penuh satu bulan sesuai dengan Undang-Undang Nomor 36 Tahun 2009 tentang Ketentuan Umum dan Tata-Tata Cara Perpajakan (KUP) Pasal 9 ayat (2a).

Setelah melakukan penyetoran Pajak Penghasilan Pasal 21 Dinas Pendapatan Pemerintah Kota Cimahi wajib melaporkan hasil penyetoran Pajak Penghasilan Pasal 21 atas gaji dan upah ke Kantor Pelayanan Pajak Pratama Cimahi (KPP). Formulir yang dilaporkan yaitu Surat Pemberitahuan (SPT) Masa yang dibuat minial dua rangkap yang terdiri dari :
1. Lembar ke satu : Untuk KPP.
2. Lembar ke dua : Untuk arsip pemotongan pajak.

Adapun beberapa Laporan Surat Pemberitahuan (SPT) Masa ini harus dilengkapi dengan menggunakan :

1. SPT Masa PPh Pasal 21.

2. Daftar bukti pemotongan PPh Pasal 21.

3. Surat Setoran Pajak (SSP) lembar ke tiga.

Berdasarkan hasil penelitian penyetoran dan pelaporan Pajak Penghasilan yang dilakukan oleh Dinas Pendapatan Pemerintah Kota Cimahi pada tahun 2015 terdapat $91,67 \%$ pelaporan yang sesuai dan $8,33 \%$ yang tidak sesuai dengan peraturan perundang-undangan perpajakan. Sejak tahun 2013 sampai tahun 2014 Dinas Pendapatan Pemerintah Kota Cimahi tidak melaporkan pajak penghasilan dikarenakan kurangnya kesadaran akan kewajibannya melaporkan pajak. Menurut Undang-Undang perpajakan penyetoran Pajak Penghasilan Pasal 21 dilakukan 10 hari setelah masa pajak berakhir, dan untuk pelaporan Pajak Penghasilan Pasal 21 dilakukan 20 hari setelah masa pajak berakhir. Oleh karena itu Dinas Pendapatan Pemerintah Kota Cimahi dikenakan sanksi administrasi berupa bunga sebesar $2 \%$ (dua persen) atas keterlambatan penyetoran dan sanksi administrasi berupa denda sebesar Rp.1.000.000,atas keterlambatan pelaporan pajak.

\section{Rekapitulasi Analisis Perhitungan PPh Pasal 21}

Dari hasil analisis yang dilakukan, penulis mencoba merekap dan membandingkan Pajak Terutang Dinas Pendapatan Pemerintah Kota Cimahi dari tahun 2013 sampai dengan tahun 2015. Berikut ini adalah hasil rekapitulasi dan hasil perbandingan analisis perhitungan dari tahun 2013 sampai tahun 2015 :

Tabel 8. Rekapitulasi PPh Terutang Pasal 21

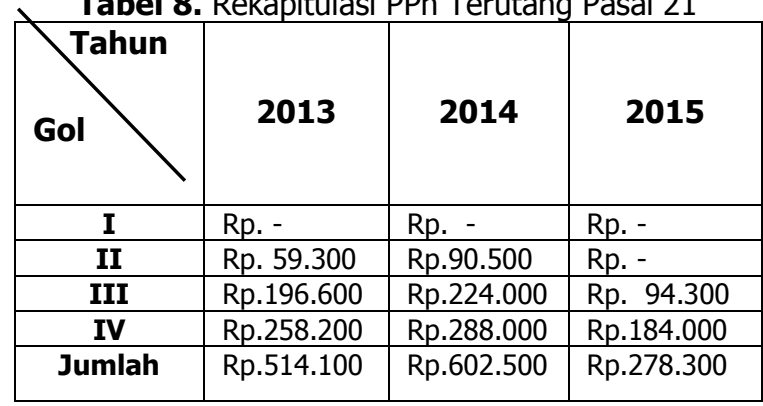




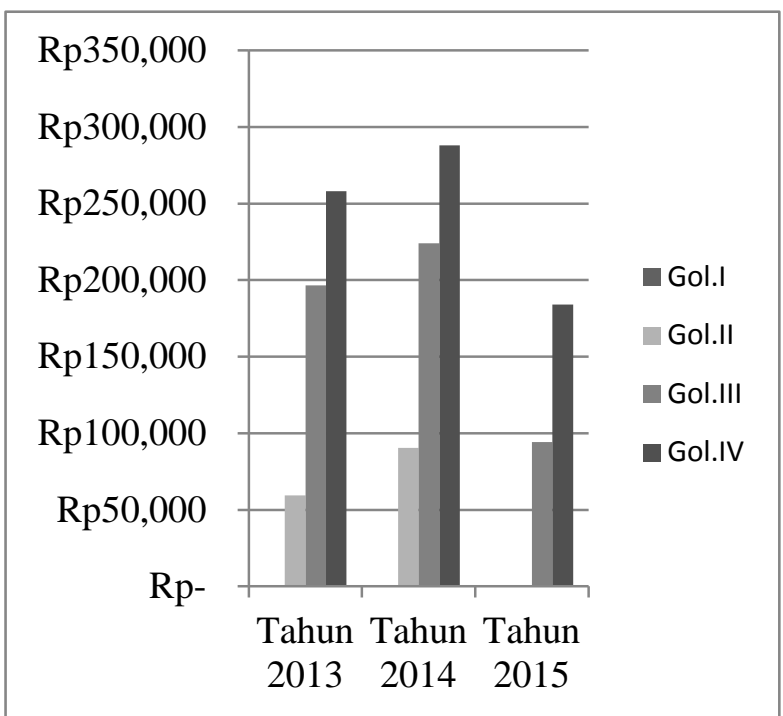

Sumber : Data diolah (2017)

Gambar 1. Grafik PPh Terutang Pasal 21

Berdasarkan Hasil Analisis Perbandingan pada tahun 2015 Pajak terutang Golongan II sampai Golongan IV mengalami penurunan dikarenakan adanya kenaikan Penghasilan Tidak Kena Pajak (PTKP) sebesar $48 \%$ atau setara dengan Rp.11.700.000,- yang mengakibatkan PNS Golongan I dan II tidak terutang pajak dikarenakan penghasilan yang diperoleh kurang dari Rp.3.000.000. Dari tahun 2013 sampai tahun 2014 pajak terutang golongan I sampai golongan IV mengalami kenaikan, faktor yang mempengaruhi kenaikan tersebut adalah meningkatnya tunjangan beras dari tahun ke tahun. Harga beras pada tahun 2013 sebesar Rp.6.979 dan harga beras tahun 2014 sebesar Rp.7.242.

\section{KESIMPULAN}

Berdasarkan hasil analisis yang dilakukan pada Dinas Pendapatan pemerintah Kota Cimahi dapat disimpulkan bahwa :

1. Pemungutan Pajak Penghasilan Pasal 21 pada Dinas Pendapatan Pemerintah Kota Cimahi telah sesuai dengan Peraturan Menteri Keuangan Nomor 262/KMK.03/2010. Untuk pemungutan Pajak Penghasilan Pasal 21 pada tahun 2015 dilakukan terhadap pegawai negeri sipil dengan tingkat golongan III dan golongan IV. Hal tersebut dikarenakan objek pajak dengan golongan tersebut memenuhi kriteria dasar pengenaan pajak. Sedangkan untuk pegawai negeri sipil tingkat golongan I dan golongan II tidak dipungut pajak dikarenakan penghasilan yang diterima kurang dari Penghasilan Tidak Kena Pajak (PTKP).

2. Perhitungan Pajak Penghasilan Pasal 21 pada Dinas Pendapatan Pemerintah Kota Cimahi telah sesuai dengan Undang-Undang Nomor
36 tahun 2008. Dalam perhitungan Pajak Penghasilan pasal 21 yang menggunakan PTKP terbaru tidak sesuai dengan Peraturan Menteri Keuangan Nomor 122/PMK010/2015 karena menurut peraturan tersebut PTKP yang baru digunakan mulai tanggal 1 Januari 2015, sedangkan Dinas Pendapatan Pemerintah Kota Cimahi baru menggunakan PTKP terbaru pada bulan November 2015.

3. Pelaporan Pajak Penghasilan Pasal 21 pada Dinas Pendapatan Pemerintah Kota Cimahi dikatakan masih tidak sesuai dengan UndangUndang Nomor 36 tahun 2008. Pelaporan pada tahun 2015 terdapat 91,67\% pelaporan yang sesuai dan $8,33 \%$ yang tidak sesuai dengan Undang-Undang Nomor 36 Tahun 2008. Untuk tahun 2013 dan tahun 2014 Dinas Pendapatan Pemerintah Kota Cimahi tidak melaporkan pajak penghasilan pasal 21 dikarenakan kurangnya kesadaran akan kewajibannya melaporkan pajak.

\section{DAFTAR PUSTAKA}

B.llyas, R.S., (2011), Ensiklopedia Perpajakan Indonesia, Jakarta: Salemba Empat.

Djajadiningrat, S. I., (2013), Perpajakan Teori dan Kasus, Jakarta: Erlangga.

Mardiasmo, (2010), Perpajakan. Yogyakarta : Andi Offset.American Institute of Certified Public Accountants, "Statememnt on Auditing Standard No. 48”, New York, 1982.

Menteri Keuangan Republik Indonesia, (2010), Pegawai Negeri Sipil, Melalui, diakses 22/11/2015

Pohan, C. A., (2011), Kajian Perpajakan dan Tax Planning Terkini, Jakarta: Bumi Aksara.

Purwono, H., (2010), Dasar-Dasar Perpajakan dan Akuntansi Pajak, Jakarta: Erlangga.

Resmi Siti, (2010), Perpajakan, Jakarta: Salemba Empat.

Sumarsan, T., (2010), Perpajakan Indonesia, Jakarta: Indeks.Baridwan Zaki, "Sistem Informasi Akuntansi”, BPFE, Edisi, Yogyakarta.

Direktorat Jenderal, (2015), Undang-Undang Pajak Nomor Per-32/PJ/2015 Tentang Tata Cara Pemungutan Pajak Penghasilan Cushing, Barry E, "Sistem Informasi Akuntansi dan Organisasi Perusahaan", Erlangga, Edisi, Jakarta.

Undang-Undang Perpajakan, (2008), UndangUndang Nomor 36 Tahun 2008 tentang pedoman Teknis Tata Cara Pemotongan, Penyetoran, dan Pelaporan Pajak Penghasilan Pasal 21, Jakarta. 